\title{
Human Dimensions in Providing Services in the Electronic Business Environment of the Travel Agencies
}

\author{
PhD candidate Hristina Santana \\ University of Economics - Varna, Varna, Bulgaria \\ hristina_santana@ue-varna.bg
}

\begin{abstract}
The current publication is focused on the human aspect and its dimensions influencing servicing in the travel and tourism industry, specifically - the travel agency, in a situation of highly expanding electronic business environment. The author's purpose is to present the impact human dimensions have upon travel agencies. Is human nature a factor to be considered when e-technology in business steps in? What are the opportunities for the stakeholders to avoid mistakes in attracting and keeping customers by launching e-business initiatives and offerings? The author has tried to reveal the integrant relation between technology and people and the importance for the travel agent professionals of keeping the balance in developing e-business, respecting the human presence as both a provider of services and consumer.
\end{abstract}

Keywords: electronic business environment, human aspect, tourism

JEL Code: Z320; doi:10.36997/IJUSV-ESS/2019.8.3.37

\section{Introduction}

The electronic business (e-business) environment of the travel and tourism industry is enormous and is faster growing in the recent years. Its accelerated development brought various effects to the stakeholders - some finding a niche for business initiatives, others still disputing the positive results of the occurrence. To create a successful and profitable business achievement, the travel professional is obliged to acquire specific talents. They are hardly to be precise as they represent a specific combination of intuition, entrepreneur skills, vision in achieving business goals, interpersonal skills, innovative thinking. The initial role of the service provider in any industry is to generate repeat customers - a key role to stay among other competitors. And to bring and keep this role into perspective, professionals simply ought to enhance the realization that - "Sales is about getting customers for your company. Customer service is about keeping them" (IATA, training book, 2018). The e-business facilitates offer provision and sales as an integral part of digitalization of economies, social and demographic structures and organisations and transforms easily into an appealing tool to customers and users. The levels of apprehension are various, but its role and characteristic advantages are indisputable, as travellers embrace digital channels for travel bookings and rely on mobile technology in undertaking business or recreational trips. The overall travel and tourism market registers continuous growth in electronic purchasing and the forecasts state there will be a stable increase in the coming years.

The object of the current publication is the electronic business environment of the travel agencies, the main subject of the study - is the role human aspect plays in providing services in a situation of widely spread e-sales. The author's purpose is, by making a short theoretical and historical review on e-business, revealing some practical approaches and examples in servicing, to present the impact human aspect and its dimensions have upon travel agencies (considering both: tour operators and travel agents intermediaries as a common term) and their customers.

The author's attempt is to emphasize on current and working trends in service models in combination with the technological improvements implied in the travel and tourism industry. Using the methods of induction and deduction, analysis and synthesis the aim is to present a general study of the effects human aspect has on the travel professionals - the tour operators and travel agents and their customers in making decisions, considering the expansion of e-business. 


\section{Electronic Business Environment}

The electronic business environment is often referred to as the enormous field of initiatives, trade and e-commerce the Internet is ready to provide often as a complimentary tool to the traditional business models. The e-business itself is considered to be a revolutionist approach in regard with the extremely easy and quick global reach, the averagely low costs in maintenance, efficient interactions between customer and provider, on-time payment transactions, faster feedbacks and commentary.

Historically, it is in the early 90-ies of the previous age, when the Internet or the World Wide Web outdraws its occurrence and brings thorough change in the business models of the stakeholders. A virtual network and reality has been launched providing versatile opportunities for communication, access to information and data exchange, electronic trade and commerce, launch of electronic markets. And if the term e-commerce relates to specific trade processes on the e-market such as purchase and sale through e-shops, e-business includes any commercial activity, using "the net", any form of online performance, including e-commerce as well.

Others consider the idea of e-business occurred long before Internet has appeared and even become popular. During the 1970-ies specific financial networks, based on innovative software and hardware decisions establish the EDI (http://www-it.fmi.uni-sofia.bg, 2018) - electronic data interchange, which in its essence represent an early form of e-business. Internet enframes and stimulates such business activities, providing opportunities not only to the big corporations, but to smaller organisations, such as travel agencies.

As the early scholars maintain, there is no doubt, e-business and commerce providing different kind of goods and services include "after-sales support or online legal advice" (Timmers, 1998). Other authors consider that the larger the scope of business, the greater the demand for IT investment (Dewan et al., 1998; Hitt, 1999; Teece, 1980), facilitating a working electronic environment. Business fast-growing digitalization can actually reduce internal coordination costs (Hitt, 1999), and e-business is stated to have the ability to lower search costs for both sellers and buyers (Bakos, 1998).

More recent authors adopt the definition of E-business as the electronic process of negotiating, performance and post processing of business interactions between commercial subjects all over the Internet (ECaTT, 2000). Thus, a more facilitative business environment has been created - a place to develop new type of marketing and sales - Web marketing, online selling and even online procurement (ECaTT, 2000). Moreover the electronic business environment seems to be able to achieve demand aggregation and improve inventory management (Zhu and Kraemer, 2002), which motivates even travel professionals to adopt e-business. Contemporary tour operators and travel agencies with greater scopes and vision have more potential to benefit from synergy between e-business and traditional business processes. Typical examples are - using their own web pages as not only a tool to perform the organisation, but to provide real search, to help consumers locate physical spot, or even establishing an online travel shop.

In this way of speaking, e-business is no longer a phenomenon dominated by large firms(Zhu and Kraemer, 2009), as more and more organisations from the travel and tourism industry engage in e-business and online sales, as it seems to be of a special advantage for small travel agencies. No doubt, large tour operators have the financial ability to develop e-commerce, to achieve better economies of scale by adopting e-business initiatives, to invest in technological innovation and projects, such as blockchain technologis. The blockchain can be considered as a digital account book or cash book and when a transaction takes place, the corresponding data is registered on the block chain by special form of encryption. The TUI recognized the signs of the new time and implemented its own internal blockchain called Bed Swap in order to optimize the load control of hotel beds and transnational transaction processes (Travel magazine, 2016). The technological system innovation proves its worthedness and diminished costs.

E-business, by nature, offers and facilitates best conditions for such technologies. The 
communication between competitors, supplier of services, travel providers of any level of the industry improves and takes place on a certain arena of business. This specific area becomes easily identified as an entirely new type of environment - electronic business environment.

Underlying into the context of technological and electronic development and innovation, many authors try to emphasize on the excessive need of IT and computerized support, crucial for the above mentioned new environment( Kotler et al, 2017). And modern tourism is closely linked to development (http://www2.unwto.org, 2019), to the environmental turbulence, caused by the Internet-based interactive media forms (Eagle et al, 2015) and versatile electronic channels. The technical skills involved by all means are valuable when speaking of electronic business provision, however interpersonal skills have also a significant role in keeping customers, to make them feel valuable. Only by personalizing service to the customer, even in an electronic form of providing, travel agents can benefit from positive impact and generate repeat customers, thus assuring company's place in the business environment. Key issue in the discussed above relationship becomes the human dimensions on the matter, as considered from both sides - the customer's and travel professional's one.

\section{The Human aspect and the travel agency}

Researches onto consumer behaviour are mostly focused on questions like who, what, why, when and how that determines decisions taken. Disciplines as psychology, sociology, anthropology and economics often blend in (Pearce, 2011), in order to have a better understanding of the human aspect in decision-making. Humans have their own individual way to behave in the world surrounding them. They tend to find different styles of comfortable models in comprehending life and all its variable nuances. And as every human sees the surrounding environment in a different manner, a real scenario of dealing with every single individual is compulsory to be adopted. Some tips to point out as important to the author's publication are described in fig.1:

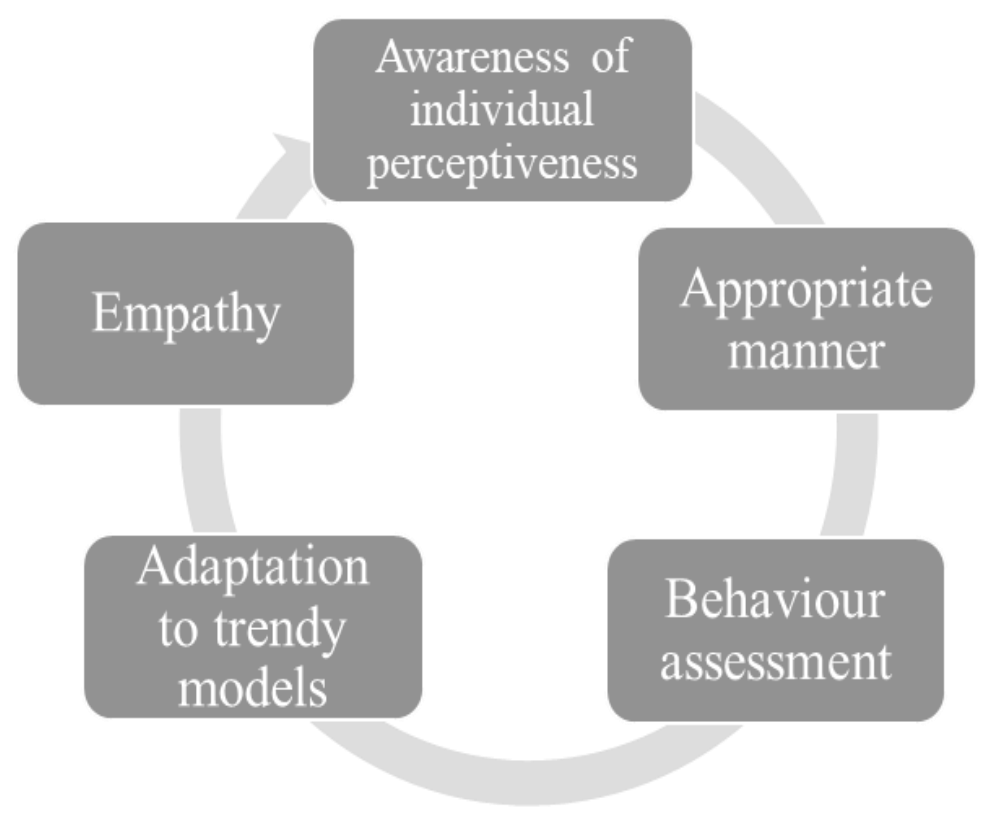

Figure 1. Styles of dealing with customers (Created by the author)

Learning about human's behaviour allows every travel agent and professional to become more sensitive and attentive to different type of customers. Being aware of individuals' perceptiveness, assures effectiveness and providing the exact service to the right person (IATA training book, 2018). Consumer behaviour is being dynamic as determined by individual 
motivation, reactions to certain travel products, brands, quality category and the previous experience factor. According to Hoyer et al. (2012), there is a wide range of factors that can affect consumer behaviour in different ways and conventionally can be divided into four broad categories:

$>$ Situational;

$>$ Personal;

$>$ Social;

$>$ Cultural factors.

Situational factors impacting consumer behaviour may include location, environment, timing and even weather conditions (Hoyer et al., 2012). In order to benefit from situational factors major retailers attempt to construct environment and situations in stores that motivate perspective customers to make purchase decision.

Personal factors, on the other hand, include taste preferences, personal financial circumstances and related factors. The impact of personal factors on consumer decision-making is usually related with market segmentation, targeting and positioning practices by grouping individuals on the basis of their personal circumstances along with other criteria, and developing products and services that accommodate these circumstances in the most effective manner.

According to Hoyer et al. (2012) social factors impacting consumer behaviour arise as a result of interactions of perspective consumers with others in various levels and circumstances. Targeting members of society perceived as opinion leaders usually proves effective strategy when marketing products and services due to the potential of opinion leaders to influence behaviour of other members of society as consumers.

Lastly, cultural factors affecting consumer behaviour are related to cross-cultural differences amongst consumers on local and global scales. Culture can be defined as "the ideas, customs, and social behaviour of a particular people or society" (Oxford Dictionaries, 2015) and the tendency of globalisation has made it compulsory for cross-cultural differences amongst consumers to be taken into account when formulating and communicating marketing messages.

Observing and assessing one's behaviour leads to different styles of dealing with customers, creating the ability to apply specific approach and effortless communication. Adapting to any forms of trendy models shows respect to the customer and discovers travel agent's goal to establish a trustful relationship, totally different from the idea of trying to manipulate them. In combination to the empathy, mandatory to any form of human-to-human communication, a service provider must feel ready to adjust to wide variety of circumstances, share understanding of situations if their aims include increasing customers' satisfaction.

Consumer behaviour and human aspect are subject of enquiry and research for the scholars since 1960, when the first books on the topic were released (Engel et al., 1968; Howard and Sheth, 1969). Journals on consumer behaviour research and economic psychology, launched in 1974 and 1982, aim to perform the widening of scope on the academic side. Later on, the matter attracted tourism scholars and the human aspect and behaviour gained interest and potential for further surveys and investigations. Many conference initiatives have been created, subjects into the curriculum of tourism schools have been introduced and a symposium on consumer psychology of tourism hospitality and leisure has been launched in 1998 (Pearce, 2011) as it became clear the importance of knowing human behaviour in order to generate and improve business opportunities.

Academic and non-academic sources provide different methods for responding to customers and their needs. Either assertive or non-assertive, insensitive versus sensitive styles create different effects of approach (IATA training book, 2018). To perform firm and fair, less aggressive or too passive behaviour is often considered to be a flexible style in dealing with human customs or manners as people are willing to perform a wide range of behavioural characteristics. For the travel agent - to clarify, react and respond to individual human characteristics and demands leads to arranging alternatives in supplying a solution to certain situations. Being already a service provider or intermediary, the agent becomes a psychologist. A belief is ought to be adhered to - The 
Effort required is worthwhile. For the purposes, the author is trying to follow, another distinction is ought to be done when speaking about human dimensions in the e-business environment (fig.2):

$>$ Considering human aspect as labour force

$>$ Considering human aspect as customer profile

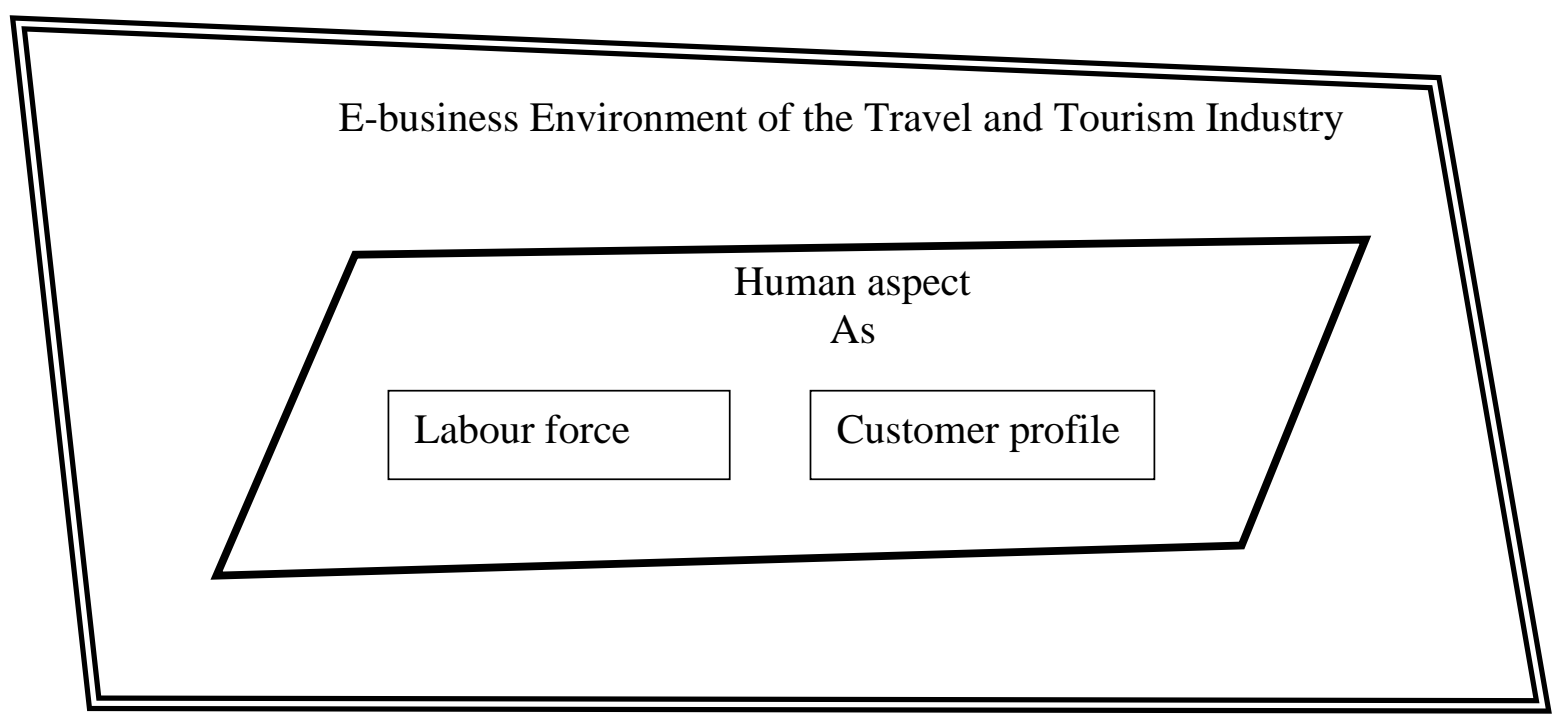

Figure 2. Human aspect in the travel and tourism e-business environment

(Created by the author)

The figure above demonstrates the author's apprehension of the irregular and disproportional form of the e-business environment, keeping constant changes and expansion in range and opportunities, and the central position the human aspect occupies in this asymmetric field of the travel and tourism industry. Tourism business is entirely depending on people - consuming, providing services, interacting, creating experiences, living the experiences. The expanding ebusiness environment supports and relates to all kind of human interactions and the human nature has significant influence on any activity and process of the value chain. That is why the important distinction in human dimension has to be outlined:

\section{Human aspect as labour force}

Every organisation is influenced by the number, qualification and specialization of the labour force engaged in the daily activities. Tour operators and travel agencies are also very sensitive to the specifics of skills employees possess in the form of personal abilities and are willing to deploy and develop, bringing positive effects to the business. No matter if it is a Trans National Corporation, or a single private travel shop the effects range on the other hand on employment, further job creation, improving the quality of labour and its remuneration - such as skills development, productivity and wages (Gillies, 2012).

Training of employees is also crucial for any organisation and it takes place right after orientation takes place. Training is the process of enhancing the skills, capabilities and knowledge of employees for doing a particular job (https://www.managementstudyguide.com, 2019). It has positive effects on both employers and employees, as an employee becomes more efficient and productive if he is trained well, which levels up company results and improves working and situational environment. Better performing on the side of personnel skills and achievements, guarantees greater interest and loyalty from the clientele's side. Training in the recent years is 
especially compulsory matter, as it is evident, customers enjoy and have positive attitude towards technological innovations, but keep on respecting and expecting human service as the basic feature in the process of tourism product consumption. And training the actual and proper styles of servicing underlies in the strategy of any respectful company or organisation. Training familiarizes new employees with the organizational mission, vision, rules and regulations and the working conditions and the existing employees are trained to refresh and enhance their knowledge. When promotion and career growth becomes important. Training is given so that employees are prepared to share the responsibilities of the higher level job or make a smooth passage during new technological equipment implementation.

The latest technologies and organizational methods often divide the production process into different components requiring different levels of skills. For the travel organisation, a strategy of utilization labour force is often considered as an efficient tool in regard with financial results and cost diminishing. Minimum number of employees, higher increase of technological supply and innovation, replacing human-job positions with technical platforms, often operated by a single person - a specialist, qualified to combine different skills. Easy transmission of data and documentation, access to partnering platforms in real time, globalization in communication worldwide brings a total new apprehension - human factor has less influence on daily technical routine. Many activities by travel agents are being shifted to the global network, which results into a gradual decline of traditional travel spots.

The classical distribution channels in the form of tour operators, who were engaged in a search to present an offer and organize the journey afterwards, more often started losing position and preference by the customer. This fact eventually made company managers reconsider the need of big number of employees, as there are less market segments - corporate clients or government authorities that are still attracted to the traditional approach in organizing certain travel, team building or special event.

The many online travel agencies have turned into opponents of the physical ones by stealing random and loyal customers. Not having to pay big rents, salaries and social security, invest in charming office places, situated in a downtown core, Travel Company owners prefer to transform their traditional business into the e-business environment as well. Investments in pompous grand offices, staff and training, physical outlook and appearance are lesser and become more tempting for the managerial teams.

Tour operators still engaged in incoming tourism, keep their back-offices to establish partnerships with foreign tour operators, arranging hotel accommodation, handling, transportation and sub-suppliers contracting. A small part of them keep an outgoing office - a travel agency as a form of advertisement and physical appearance, a so called - face out. Some of the offices consist of a travel consultant or two, combining several duties starting from typical travel arrangement ones continuing to primary accounting and technical supply. More often travel office owners try to attract a multifunctional labour force, the employee must be an accredited IATA and GDS agent, bachelor or master degree graduate, at least one-two year-experienced, often a requirement settled to have his own list of attracted customers.

It is not unfamiliar to managers to seek for a final product in the face of the employee, than to having needed to create one, suitable for the working environment. In a global aspect many developing countries, as Bulgaria, for example have "pockets of skilled labour which can be bought at much cheaper rates than the corresponding labour in developed countries" (Gilles, 2012) This all is part of the globalisation process, driven by economic forces, resulting in reorganisation, integration and adoption of well-proved practices ( Buckly, 2011). The latest provide opportunities in the form of new-working methods for small and large firms to enjoy the global market outsourcing models. And it is not only the typical outsourcing and software engineers, investors are interested in, even in the travel and tourism industry similar trend is starting to flourish.

One of the well-known MICE and business travel organisations opened office in Varna, 
Bulgaria. Officially registered in Stuttgart, Germany, profiting from the respected national name, the brand operates worldwide, arranging trade fair, congress events, specialized forums, support and accommodation to the participants. The employees engaged are local and possess perfect language and communicative skills, being well-trained members of the classical hospitality business. Adopted manner and service models are easy to be performed through telephone communication with the customer and improved internal hotel reservation platform, not needing to stand in front of the customer. The company offers economies of scale, by optimizing booking process and in the meantime, appointing personal account manager at no extra cost. The focus is on the corporate customer, company's aim - to ensure valuable services and dedicated customer support (https://www.fair-point.com/our-partners//, 2019). The company has achieved a good symbiosis making a profitable business, long-term partnership, loyal customers and satisfied employees. The managers have concluded - human aspect has major impact on business. Wage scales, social package, working conditions, team-building activities - they are all part of the whole product and in the meantime - economies of scale for the organisation, as business is actually situated in Bulgaria.

A successful business relies specially on labour force. No matter the level of technological innovations installed, human presence and interpersonal communication have major effect on customers, which leads us to the second distinction to be reviewed.

\section{Human aspect as a customer profile}

Technological changes, including the rise of e-commerce, have made global operations cheaper and more manageable (Buckly, 2011). Internet, Travel companies' websites, travel blogs even the current social media channels represent a substantial field for easy-accessing commercials for cheap holiday offers, numerous great-value-for-money packages, do-it-yourself airline tickets and all kind of gadgets to facilitate a journey or travel plans (Santana, 2018).

Being a dynamic and competitive sector of the national economy, the travel and tourism industry has the ability to adapt to the constant changes of customer needs and desires. Travel professionals keep on improving electronic selling channels as they meet the new category of customers - Internet ones. The industry has actually started identifying consumer needs and aims to develop product, pricing policy, distribution and promotion as effectively as possible, and the result will be - attractive product and satisfied tourist (Kotler et al, 2014). Keeping the thread of thoughts, considering the human aspect by identifying the customer profile stands on as a crucial part of the marketing policy of any business organisation, the travel agency's as well. Personal name records, for example, are not unfamiliar to the airplane travel industry and are in use for many years. They stand as the mandatory characteristic, when preparing airplane ticket and journey and facilitate the work of the ticketing agent and the air company, comprising all necessary data for the passenger. In turn the customer is released from the need to provide the booking company with necessary data information every time they are undertaking a journey, and as a personal amenity - also making them feel meaningful and recognizable by the institution.

The travel and tourism industry customer is quite different from the previous consumer generations. He is not only tech-orientated, but is also expecting service quality and is striving for the real experience to go with it. This new type of Internet customer forms entirely new category of tourist - "the online tourist", who is always eager to know more, and is communicative, possesses vivid individuality and personality (Marinov, 2004, p. 116). The online tourist is also a subject of keeping record of. Either by the traditional travel agent, or the online one, or even by the tracking system of the online travel channels visited by the potentional customer. In this way of speaking, customer is always being monitored for bad or for good, their every step in the e-business environment is being followed and often being targeted by certain companies, trying to attract them as a client, offering them new products and services, or as stated - different kind of experience.

Customers nowadays are practically starting living differently. According to some authors most of the consumers tend to improve their lives by attempting to work and spend less, but 
tempted by different fashion trends and encouraged by commerce (Robinson, 2006), and today by e-commerce and e-business, are actually spending more and more. Schor (2004) considers advertisements as tool of commercialization of childhood, socializing the upcoming generation into the work-and-spend-cycle. In the recent years, according to others (Aall et al, 2011) leisure consumption has been fast accelerating than general consumption itself. Personal professional experience and interviewing co-partners from the travel and tourism industry in Bulgaria, prove and reveal that many customers tend to cut costs on general expenditure and in turn to spend more on travel packages and journeys to long-distance sites, on more luxury trips and less-cost saving travel amenities. And all business, travel and tourism included, are seeking the best ways to attract more customers and to make them loyal, to persuade existing customers in purchasing more often (Roberts, 2015). Travel professionals started registering another group of customers, who prefer to travel more often, at least twice or three times per year, on national holidays, shortening trip periods of stay, but aiming to change constant living and gain more entertainment experience.

Business models are endeavouring to expand on the travel in tourism market, some of them comprising technological innovative approaches, as to suit the rise of the high-tech wave in society, while others are more likely to apprehend the so called ethical model in service. Not all customers prefer communicating through the Internet, especially when tourism activities are being involved. They are likely to apprehend the real distinction between providers and clients, as there are benefits on both sides - some people prefer to being served to some extent and at any rate (Roberts, 2015).

For the travel agency - the real face-to-face communication removes boundaries and provides hints in best offering, persuading, clarifying and stimulating further purchasing. Though at times human-to-human communication is challenging and time-consuming matter, it brings more benefits to the parties involved as it allows people to share opinions, make comments, ask for details and in turn being answered to in the better plausible way. Dealing with customer complaints and receiving after-holiday feed-backs is also typical human-to-human interaction. Sharing opinions to others either through the social media, or to the personal travel agent or co-partner (in a B2B communication channel or classical tour operator-intermediary communication) is a way to enrich travel information, product and service quality, deepen connection - provider of services - end consumer. And if advertisement is the reason for leisure and tourism activities to be fast growing in the past hundred and more years in the sense of holiday-making, eating and drinking out of home, let the travel agent professional determine the best way of providing the proper good, to the proper customer in the proper manner.

The new models of travel and tourism business, the electronic environment, encourage tour operators and travel agents to change scope in a way of homogenising tourism offers provision. The business is reducing its attempts and manner in seeking out the wealthy customers while neglecting the masses. The world wide web, the opportunities the electronic environment creates, enables travel agency professionals with alternatives to fight domination by monopolies (Buckly, 2011). It gives alternatives to the smaller agents to gain partial competitiveness, to improve service models and thus to keep position on the market.

Managing nowadays tourist is a sophisticated matter. Hotel chains, restaurants, entertainment parks, airline companies, traditional tour operator and travel agencies promote competitive offers, trying to appeal to greater number of potential and real customers. Various electronic channels are at customers' disposal in order to provide more and more information, comments and suggestions. Social media has extremely great influence on its users and affects human behaviour, interests and imagination, creates inclinations on specific electronic purchases and stimulates e-business environment. But managing this kind of business still relies on the human aspect and its dimensions in regard to the personal psychological profile of the customer and the characteristics identifying human nature. Assessing customers' attitude towards innovation is subject on many surveys and scholar studies. Knowing your customer, his certain needs and preferences is the best way to attract and keep his loyalty. And in the end it all comes to the human 
customer questioned, possessing special psychological features, personal individuality, versitile nature and expectations.

\section{Conclusion}

To arrange a better insight of the tourism issues, to fight service limitations, to create and develop e-business, tour operators and travel agents meet the necessity to find the balance between human aspect and technological approach. The reason for the statement is deeply rooted in the idea that people communicate with people. No matter if the Network is involved, the influence of the social media, travel blogs or online exchange channels there is the human-to-human relationship. The customer is actually listening to other customers, the electronic channel is just the means to reach greater audience and clients at relatively less costs. Before taking the decision to buy or not to buy certain product or service, every customer researches the net, asking for advice and comments by other customers, studying characteristic and reviews, weighs the pluses versus the minuses and finds the best way to make the purchase. And travel and tourism industry is more related to human communication than any other business. Travel agency professionals already started thinking out of the box in order to react and respond to the needs of the contemporary search of the highly techorientated traveller, to provide the best service and unforgettable experience either in the style of traditional business model or using the advantages of the e-business environment.

\section{References}

1. All, C., A. Engeset, I. Klepp, S. Skuland, Leisure and sustainable development in Norway: Part of the solution problem (2011), Leisure Studies, Routledge, London, UK

2. Bakos, Y. The Emerging role of the electronic marketplace on the Internet, COMMUNICATIONS OF THE ACM August (1998)/Vol. 41, No. 8

3. Buckly, P. Globalization and the global factory (2011), Edward Elgar, UK

4. Dewan, S., Michael, S., and Min, C. Firm Characteristics and Investments in Information Technology: Scale and Scope Effects, Information Systems Research (9:3), (1998), pp. 219- 232

5. Eagle, L., St. Dahl, B. Czarnecka, J. Lloyd, Marketing communications, (2015), Routledge, London, UK

6. Engel, J.F., Kollat, D.T. and Blackwell, R.D. (1968) Consumer Behaviour. Holt, Rinehart \&Winston, New York

7. Gillies, G., Transnational Corporations and International production (2012), Edward Elgar Publishing Ltd.

8. Hitt, L. Information Technology and Firm Boundaries: Evidence from Panel Data, Information Systems Research (10:2), (1999) pp. 134-149.

9. Howard, J., J. Sheth, The Theory of Buyer Behaviour (1969) Wiley, New York

10. Hoyer, W.D., Macinnis, D.J. \& Pieters, R. (2012) "Consumer Behaviour" 6 ${ }^{\text {th }}$ edition, CENGAGE Learning, Boston, USA

11. Kotler, Ph., J. Bowen, J. Makens, Marketing for Hospitality and Tourism (2017), Harlow Pearson, UK

12. Kotler, Ph. Marketing Management (2014), Prentice Hall International, UK

13. Kotler, Ph., J.T. Bowen, J. Makens (2014), Marketing for Hospitality and tourism, $6^{\text {th }}$ ed., Harlow, Pearson, UK

14. Marinov, St. Technological innovations and Bulgarian tourism (2004). A digest of reports "Actual problems in Bulgarian tourism, Varna: Slavena Varna. (in Bulgarian)

15. Oxford Dictionaries, 2015, visited on 15.08.2019

16. Pearce, Ph., Tourist Behaviour and the Contemporary World (2011), CVP, Bristol, UK

17. Roberts, K., The Business of Leisure, Tourism, Sport, Events and Other Leisure Industries (2015), Red Globe Press

18. Robinson, J., Economic Development and Democracy, Annual reviews on political science, (2006) 9.092704 .171256 
19. Santana, H., Contemporary technological innovations in tourism (2018), Tourism and Intercultural Communication and Innovation, Cambridge Scholars Publishing

20. Schor, J. Born to Buy: The Commercialized Child and the New Consumer Culture (2005), Scribner

21. Timmers, P., Business models for electronic markets, International Journal of electronic markets, Volume 8, Issue 2 (1998) European Commission, Directorate-General III Originally published in April Bodger

22. Zhu, K., K. Kraemer, A Cross-Country Study of Electronic Business Adoption Using the Technology-Organization-Environment Framework (2002)

23. Zhu, K., K. Kraemer, Global E-Commerce: Impacts of National environment and policy, (2006), Cambridge University press

24. Travel magazine, (2016)

25. IATA training book, (2018)

26. ECaTT. Benchmarking Progress on New Ways of Working and New Forms of Business Across Europe, (2000) [available online at http://www.ecatt.com/], [Accessed on 08/06/2019]

27. https://www.managementstudyguide.com, [Accessed on 10/07/2019]

http://www2.unwto.org, [Accessed on 02/07/2019]

http://www-it.fmi.uni-sofia.bg/courses/BonI/chapter2.html_[Accessed on 03/07/2019]

https://www.economist.com/_[Accessed on 03/07/2019]

https://www.fair-point.com/our-partners// [Accessed on 09/02/2019] 